\title{
Design of small cogeneration system for public buildings in the town of Matera
}

\author{
Elisabetta Negro*, Nicola Cardinale, Gianluca Rospi \\ Università degli Studi della Basilicata, Dipartimento delle Culture Europee e del Mediterraneo, Via \\ Lazazzera snc, Matera, Italy
}

Email: ing.negroelisabetta@gmail.com

\begin{abstract}
The present work is focused on a small-cogeneration system design for three school buildings in the town of Matera on which it was conducted an energy audit in dynamic conditions in order to define energy demand necessary for the small-cogeneration system design. Cogeneration, also known as CHP (Combined Heat and Power), through the joint and the simultaneous production of electricity (or mechanical) and useful heat from a single energy source, aims at more efficient use of primary energy, with savings on production processes, where there is a strong coincidence in time between electrical and thermal extraction. Cogeneration system power is calculated as indicated in standard UNI/TS 11300-4:2016. Remarkable it is also the economic advantage through the access to White Certificates, Italian incentive system. The CHP system is designed on electricity request of the case studies analysed and its power is $90 \mathrm{~kW}$ el with a pay-back time between three and four years. In order to satisfy the entire heating energy demand for the entire district, the authors hypothesized interventions on envelope and system plant. In this case the pay-back period increased and it is between 6-7 years considering White certificates and Thermal Bill.2.0 incentives.
\end{abstract}

Keywords: Cogeneration Plant, Energy Audit, Energy Performance, Technical and Economic Feasibility, White Certificates.

\section{INTRODUCTION}

Population growth and economic development increases energy consumption.

An analysis of Italian National Energy Budget in the last decades shows an important role of the civil sector and of the impact of fossil fuels in air conditioning systems. The predominance of buildings using conventional system causes a high consumption of fossil fuels [1]. This problem causes the necessity to find new renewable energy sources characterized by a constant production of thermal and electricity energy. Photovoltaic, solar thermal and wind energy are discontinuous energy sources and, for this reason, they need the integration with other fossil sources to produce thermal and electric energy.

Most of the world's energy is currently produced and consumed faster than earth is able to restore and this compromises its sustainability. Moreover, the energy resources in the world decreased while energy needed by humanity increased. As it is stated by [2], there are two ways to deal with these problems. One of these is finding and improving new renewable energy sources such as solar or wind energy systems. The other way is to improve conventional energy converting systems for using existing energy source more efficiently and for longer time, such as cogeneration systems [2]. Cogeneration system applied to the case studies can guarantee us some proven, reliable, applicable and cost-effective solutions which could give an important contribution in global heat and electric demand reduction. Most of electric energy generated in Italy and in the world comes from thermal power plants, in which high-temperature heat is before converted into mechanical energy and then into electric energy by means of electric generators.

Cogeneration systems, also known as CHP (Combined Heat and Power), give us some significant advantages thanks to their environmental advantages. In this system, there is an increase in efficiency and a decrease in fuel use compared to other conventional processes for thermal and electrical energy production which, normally, yields a large reduction in greenhouse gas emissions.

Sustainability of cogeneration systems can be obtained using this heating system together with some renewable energy conversion systems like solar or heat pumps system. Cogeneration system can also be used together with different systems to save more energy. An example is given by the study of Burer et al. [3] and named "multi-criteria optimization of a district cogeneration plant integrating a solid oxide fuel cellgas turbine combined cycle, heat pumps and chillers". The conversion of heat into mechanical energy, which is the most complex transformation, is performed through a 
thermodynamic cycle: Rankine and Hirn cycles and the Brayton-Joule cycle in turbo-gas installations [4].

Cogeneration, using the same fuel for a combined production, uses primary energy more efficiently.

Generally, CHP systems are formed by a primary motor, a generator, a heat recovery system and electrical interconnections. The primary motor is any engine used for converting fuel into mechanical energy, the generator converts it into electric energy, while the heat recovery system collects and converts energy contained in the primary motor discharges into usable thermal energy.

As is stated in [5], combined production can increase the efficiency of use of fossil fuels of more than $80 \%$. This permits lower costs and lower emissions of pollutants and greenhouse gases compared to separate electricity and heat productions.

Unlike power plants, CHP needs small systems that are able to generate heat and electricity for large structures (i.e. hospitals, hotels, etc.) or small urban centre.

In small-cogeneration system, combustion reaches savings up to $40 \%$ in the use of primary energy sources.

Figure 1 illustrates the comparison between conventional and combined production; in the case of the combined production the total efficiency is higher than a separate production.

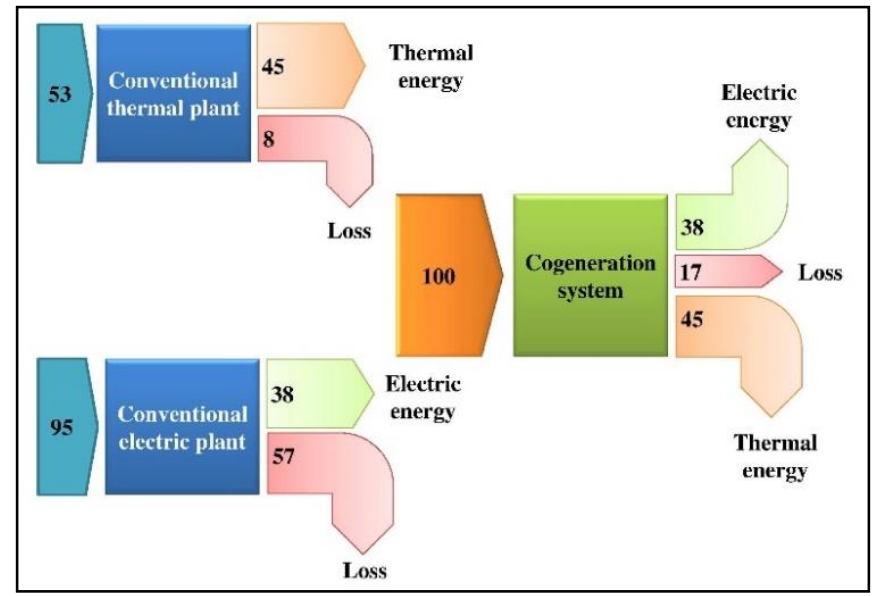

Figure 1. Separate production of electric and thermal energy versus cogeneration production [5]

As is shown in Figure 1, in separate electric and thermic productions, we need about 148 units respect to 100 units in cogeneration production. A CHP system with thermal and electrical production processes requires $35 \%$ less fuel than the electricity and heat production separate configuration.

The consequential evolution of an integrated system of cogeneration is tri-generation. It is possible, using a single source of primary energy, to obtain a production of electricity (or mechanical energy) and the heating for the cooling process. These systems present a lot of advantages especially in dairy industries when there is the maximization of operating hours, in which happens self-consumption of heat and electricity cogenerated, increases the investment convenience. [6]

As stated by [6] a district heating service, even if it has undoubted advantages from the energy point of view, it is often less efficient compared to the modern technologies. Nowadays, in fact, condensing boilers and heat pumps provide energy efficiency higher than the "traditional" district heating (steam turbines and gas). From the environmental point of view, the comparison on pollutant emissions is even more surprising, since, thanks to the many technological improvements that the boilers have had in recent years of development (low-NOx burners, modulating, premixed), their use generates a much lower environmental impact than the district heating plant (including combined cycles). To overcome this important gap, cogeneration plants should be equipped with systems to reduce pollutants much more effective than the today used [7].

\section{ENERGY AUDIT OF CASE STUDIES}

In this paper, we conducted energy audit for three buildings in the town of Matera with relevant results.

We investigated some buildings which took part of Horizon project, FESTA (Fostering local energy investments in the Province of Matera), won by Province of Matera in collaboration with University of Basilicata and Healthcare Centre in Matera (Matera ASL), owner of Policoro hospital.

Buildings analysed for cogeneration system design are: Gymnasium Lyceum "L.G. Duni”, Scientific Lyceum "D. Alighieri" and Technical Institute I.T.C "Loperfido".

These buildings are located in the town of Matera (Southern Italy), with an altitude of $401 \mathrm{~m}$ a.s.l. and it is characterized by a warm and temperate climate. The average annual temperature in Matera is about $13.7^{\circ} \mathrm{C}$. In a year, the average rainfall is about $619 \mathrm{~mm}$

Figure 2 shows geolocation of each structure.

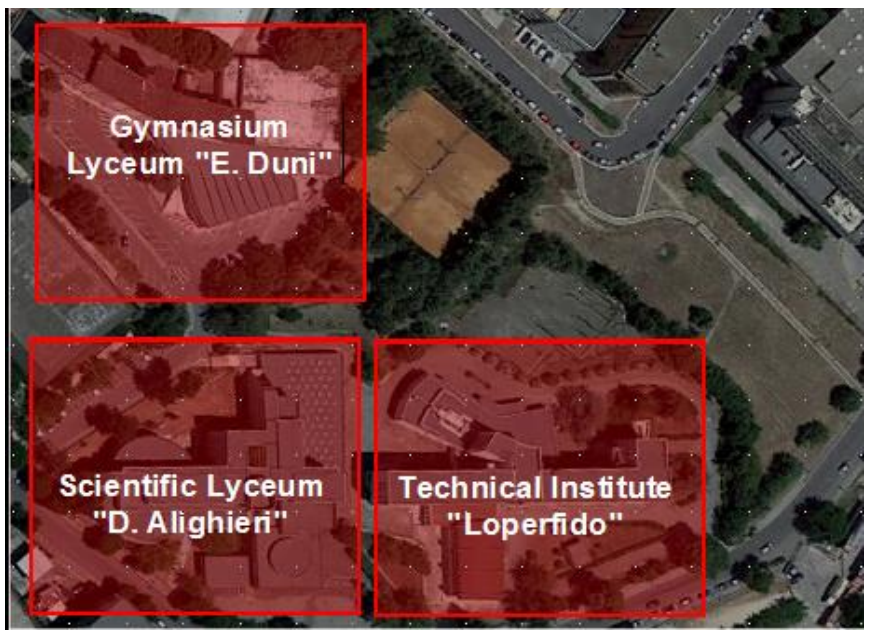

Figure 2. Buildings geolocation

All the buildings were built before the first Italian law on energy efficiency $[8,9]$ therefore they are characterized by a high heat loss of envelope.

Gymnasium Lyceum "E. Duni” (Figure 3) was built in 1966 and it is a 6-floor building. Opaque envelope is in reinforced concrete and external walls are in plastered brick. Transparent envelope is composed of single-glazed window.

Scientific Lyceum "D. Alighieri" (Figure 4) was built in 1971 and it is a 4-floor building. Opaque envelope is devoid of insulation and is made of reinforced concrete structure with external facing walls and brick-concrete floors. Transparent envelope is composed of a single-glazed with metal frame without thermal break.

Technical Institute "Loperfido" (Figure 5) was built in 1961 and it is a 5-floor building. Opaque envelope is composed of a reinforced concrete structure with external walls in plastered brick. 


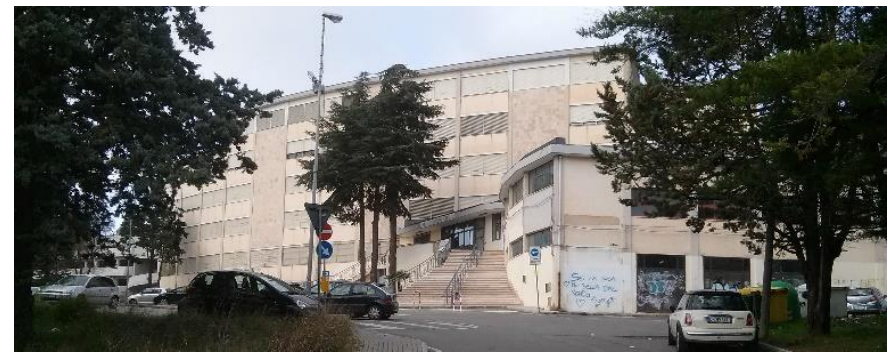

Figure 3. Gymnasium lyceum "E. Duni"

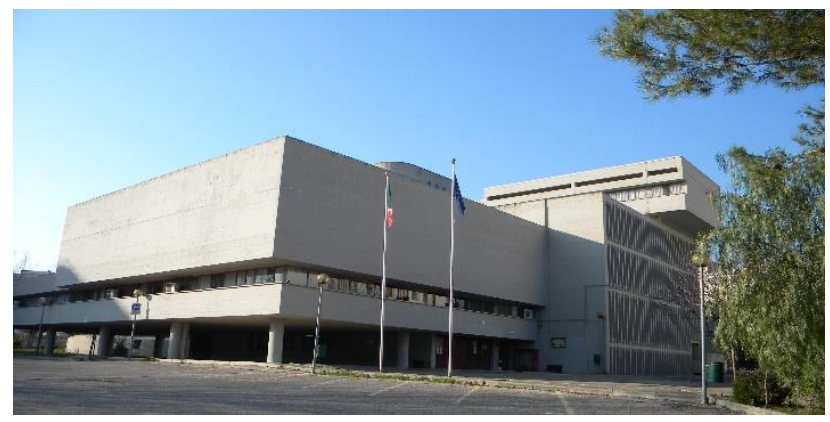

Figure 4. Scientific lyceum "D. Alighieri"

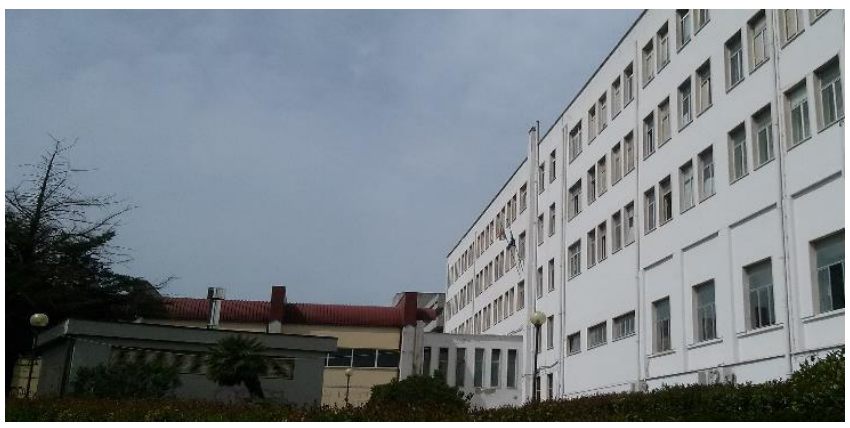

Figure 5. I.T.C. "Loperfido"

Transparent envelope is composed of a single-glazed with metal frame without thermal break.

Table 1 reports thermal transmittance obtained with measurement in situ for vertical opaque envelope applying the ISO 9869 [10]. Thermal transmittance for horizontal surface and transparent envelope was estimated using, in the first case, UNI EN ISO 6946:2008 [11] and UNI EN ISO 10077 1-2 in the second one [12].

Table 1. Thermal transmittance of buildings envelope

\begin{tabular}{c|ccc}
\hline \multirow{2}{*}{ Building } & $\begin{array}{c}\text { External } \\
\text { walls }\end{array}$ & Coverage & Windows \\
\cline { 2 - 4 } & $\begin{array}{c}\mathrm{U} \\
{\left[\mathrm{W} / \mathrm{m}^{2} \mathrm{~K}\right]}\end{array}$ & $\begin{array}{c}\mathrm{U} \\
{\left[\mathrm{W} / \mathrm{m}^{2} \mathrm{~K}\right]}\end{array}$ & $\begin{array}{c}\mathrm{U} \\
{\left[\mathrm{W} / \mathrm{m}^{2} \mathrm{~K}\right]}\end{array}$ \\
\hline L.G. " E.Duni" & 1.54 & 1.50 & 5.78 \\
\hline L. S. "D. Alighieri”" & 2.54 & 2.21 & 5.78 \\
\hline I.T.C. "Loperfido" & 2.06 & 1.60 & 5.78 \\
\hline
\end{tabular}

Energy consumptions and energy demands are related to the official hours of operation provided for the specific climate zone defined by Italian Law. For Basilicata region, which belongs to climate zone " $\mathrm{D}$ ", the heating period goes from November 1 to April 15 for 12 hours a day.
Heating system of school buildings is characterized by condensing boilers with radiators as emission terminals. Cooling system is no present (Table 2).

Table 2. Heating system characteristic

\begin{tabular}{l|cc}
\hline \multicolumn{1}{c|}{ Building } & Heating system & $\begin{array}{c}\text { Installed thermal } \\
\text { power }\end{array}$ \\
\cline { 2 - 3 } G. L. " E.Duni" & $\begin{array}{c}\text { Condensing boiler } \\
\text { with radiators }\end{array}$ & 610 \\
\hline S. L. "D. Alighieri" & $\begin{array}{c}\text { Condensing boiler } \\
\text { with radiators }\end{array}$ & 1075 \\
\hline I.T.C. " Loperfido" & $\begin{array}{c}\text { Condensing boiler } \\
\text { with radiators }\end{array}$ & 928 \\
\hline
\end{tabular}

Monthly energy consumptions were obtained during the energy audit thanks to the data given by Province of Matera. These data are used to set dynamic model using Energy Plus code [13]

Data shown in table 3 and table 4 are necessary to understand the energy request of the entire district and in order to design cogeneration system used only in winter season.

Table 3. Natural gas consumptions

\begin{tabular}{c|cccc}
\hline \multirow{2}{*}{ Month } & \multicolumn{4}{|c}{ Heating energy request } \\
\cline { 2 - 5 } & $\begin{array}{c}\text { G. L. } \\
\text { "E.Duni" }\end{array}$ & $\begin{array}{c}\text { I.T.C. } \\
\text { "Loperfid } \\
\text { o" }\end{array}$ & $\begin{array}{c}\text { S. L. "D. } \\
\text { Alighieri" }\end{array}$ & Total \\
\cline { 2 - 5 } & $\begin{array}{c}\mathrm{kWh} \text { th } / \mathrm{mon} \\
\text { th }\end{array}$ & $\begin{array}{c}\mathrm{kWh} / \mathrm{mon} \\
\text { th }\end{array}$ & $\begin{array}{c}\mathrm{kWh} / \mathrm{mon} \\
\text { th }\end{array}$ & $\begin{array}{c}\mathrm{kWh} \text { th } / \mathrm{mon} \\
\text { th }\end{array}$ \\
\hline January & 59837 & 82728 & 113189 & $\mathbf{2 5 5 7 5 4}$ \\
\hline $\begin{array}{c}\text { Februar } \\
\text { y }\end{array}$ & 68383 & 94544 & 129354 & $\mathbf{2 9 2 2 8 0}$ \\
\hline March & 64096 & 88617 & 121246 & $\mathbf{2 7 3 9 5 9}$ \\
\hline $\begin{array}{c}\text { Novemb } \\
\text { er }\end{array}$ & 37669 & 52079 & 71255 & $\mathbf{1 6 1 0 0 3}$ \\
\hline $\begin{array}{c}\text { Decemb } \\
\text { er }\end{array}$ & 50111 & 69282 & 94792 & $\mathbf{2 1 4 1 8 5}$ \\
\hline Year & $\mathbf{2 8 0 0 9 5}$ & $\mathbf{3 8 7 2 5 1}$ & $\mathbf{5 2 9 8 3 5}$ & $\mathbf{1 1 9 7 1 8 1}$ \\
\hline
\end{tabular}

Table 4. Electric energy consumptions

\begin{tabular}{c|rccc}
\hline & \multicolumn{4}{|c}{ Electric energy request } \\
\cline { 2 - 5 } Month & $\begin{array}{c}\text { G. L. } \\
\text { "E.Duni" }\end{array}$ & $\begin{array}{c}\text { I.T.C. } \\
\text { "Loperfido } \\
\text { " }\end{array}$ & $\begin{array}{c}\text { S. L. } \\
\text { "D. } \\
\text { Alighieri" }\end{array}$ & Total \\
\cline { 2 - 5 } & $\begin{array}{c}\mathrm{kWh} / \mathrm{mon} \\
\text { th }\end{array}$ & $\begin{array}{c}\mathrm{kWh} / \mathrm{mont} \\
\mathrm{h}\end{array}$ & $\begin{array}{c}\mathrm{kWh} / \mathrm{mon} \\
\text { th }\end{array}$ & $\begin{array}{c}\mathrm{kWhel} / \mathrm{mo} \\
\text { nth }\end{array}$ \\
\hline January & 8450 & 15127 & 17280 & $\mathbf{4 0 8 5 8}$ \\
\hline $\begin{array}{c}\text { Februar } \\
\mathbf{y}\end{array}$ & 8703 & 15580 & 17797 & $\mathbf{4 2 0 7 9}$ \\
\hline $\begin{array}{c}\text { March } \\
\text { Novemb } \\
\text { er }\end{array}$ & 7719 & 14819 & 15786 & $\mathbf{3 8 3 2 4}$ \\
\hline $\begin{array}{c}\text { Decembe } \\
\text { r }\end{array}$ & 8274 & 13522 & 15375 & $\mathbf{3 7 1 7 1}$ \\
\hline Year & $\mathbf{4 1 4 5 2}$ & $\mathbf{7 2 9 6 9}$ & $\mathbf{8 2 2 7 0}$ & $\mathbf{1 9 6 6 9 0}$ \\
\hline
\end{tabular}

As we can see from Table 3 and Table 4, Scientific Lyceum has high natural gas and electricity consumption respect to other school buildings. 


\section{COGENERATION SYSTEM DESIGN}

The main benefit of a CHP system respect others system is its efficiency. Environmental Protection Agency (EPA) defines "simple efficiency of a single system" as the ratio of the net electrical output and the amount of fuel consumed.

The global efficiency is given by the ratio of the sum of the useful thermal energy and the total electrical/mechanical energy produced and the fuel energy input into the cogeneration energy production system (see Eq. 1) [5].

$\eta=\frac{Q_{e l}+Q_{t h}}{Q_{c h}}$

The first advantage of cogeneration is clearly economic: a well-designed cogeneration system provides significant energy savings of $25-40 \%$.

Energy performance is equal to $70-85 \%$, a really significant value compared to the $50-60 \%$ of the new combined cycle plants for electricity production only.

To design a CHP system, it is necessary to define:

- $\quad$ Climate data;

- $\quad$ Thermal energy needs for heating and hot water;

- $\quad$ Electric energy request;

- $\quad$ Calculation interval (month);

- $\quad$ Performance data of cogeneration section.

The cogeneration plant was designed on electricity consumption of the entire district because electricity production of a CHP system is only of $32.5 \%$ respect to the heating production. If we designed CHP system on heating request, we obtained a very high production of electricity, which cannot be used by users.

The estimated cogeneration power is $90 \mathrm{~kW}_{\mathrm{el}}$, so it is a small-cogeneration plant as established by [14] because it is less than $1 \mathrm{MW}[14]$

In Figure 6, the authors analysed the covering of CHP electricity production on electricity demand for the entire district. Annual electricity demand is covered by $92 \%$.

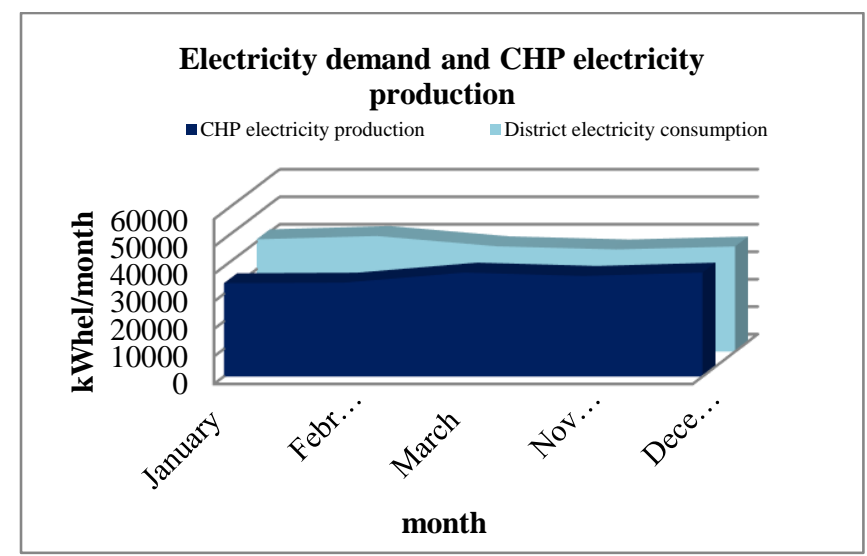

Figure 6. Electricity demand and CHP electricity production

To eliminate or to reduce the need for a timely coincidence between the thermal power output and the incoming request to the distribution system, we considered an inertial heat accumulation system. Performance under actual operating conditions will therefore be influenced by the correct sizing of the system.

In our case we installed a storage system of 5000 litre with a maximum flow temperature of $75^{\circ} \mathrm{C}$ and an average return temperature of $45{ }^{\circ} \mathrm{C}$. To have a perfect system sizing it is necessary to verify the congruity index $\alpha$ defines by UNI/TS 11300-4 [15] (see Eq. 2) as:

$\alpha=\frac{Q_{C G, s}}{Q_{C G, s, d e s i g n}}$

- if $\alpha>1$ storage is oversized but it is considered congruous

- if $\alpha=1$ storage is perfectly sized

- if $0<\alpha<1$ storage is present but no congruous

Since the demand for thermal energy is variable in the different calculation periods (month), the congruity index cannot be equal to " 1 " throughout the year, so if you want to have a more reasonable sizing $(\alpha \geq 1)$, it should be designed on the most demanding requirement.

In heating period congruity index $\alpha$ is always no congruous because its value is 0.62 . This value is acceptable because system is design to cover the maximum electricity demand but it does not cover the global thermal energy demand.

Regarding heating energy request (Figure 7), the cogeneration system designed is able to cover the $28 \%$ of yearly thermal energy needs (Table 8).

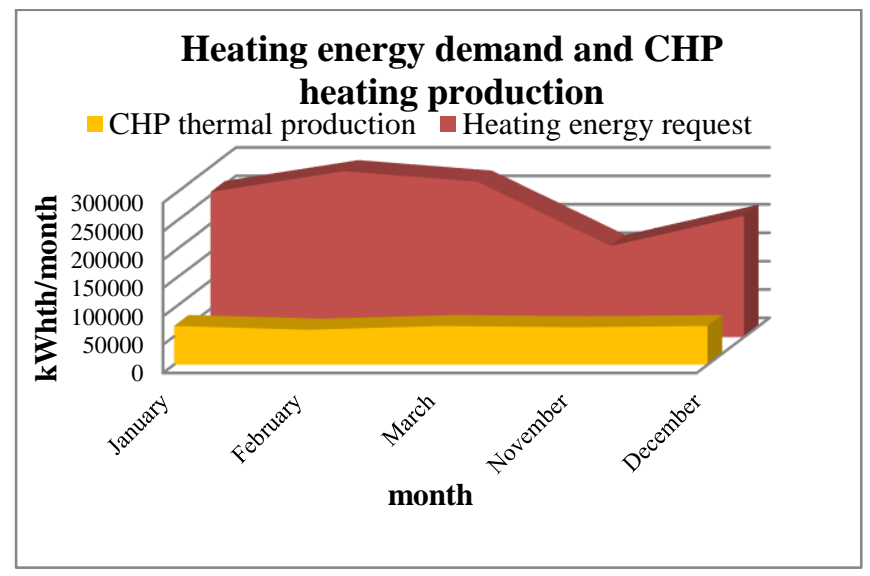

Figure 7. Heating energy request and CHP heating production

Another analysis was conducted in case Public Administration decided to improve the energy performance of envelope in order to reduce the district heating energy demand.

The authors assumed to consider only interventions that not compromise architectural appearance of buildings.

The assumed energy improvement measures are:

- Insulation of flat roof with inner coat made with thermal insulation wall, composed of a plasterboard sheet thickness $\mathrm{mm} 10$ coupled to an insulating layer consisting of panel hemp fibre with thermal conductivity $\lambda=0.030 \mathrm{~W} / \mathrm{mK}$;

- Installation of windows with double or triple lowemissivity glass, with cavity filled with inert gas and the wooden frame with finishes and colours compatible with those of the opaque walls.

Heating consumptions are estimated through the dynamic method using Design Builder interface based on Energy Plus code [13].

In the case of combined intervention on envelope and heating system, thermal request has a high reduction (Figure 8). Annual heating energy request is covered for $68 \%$. 
Heating energy demand and CHP thermal production (CHP and improving on envelope)

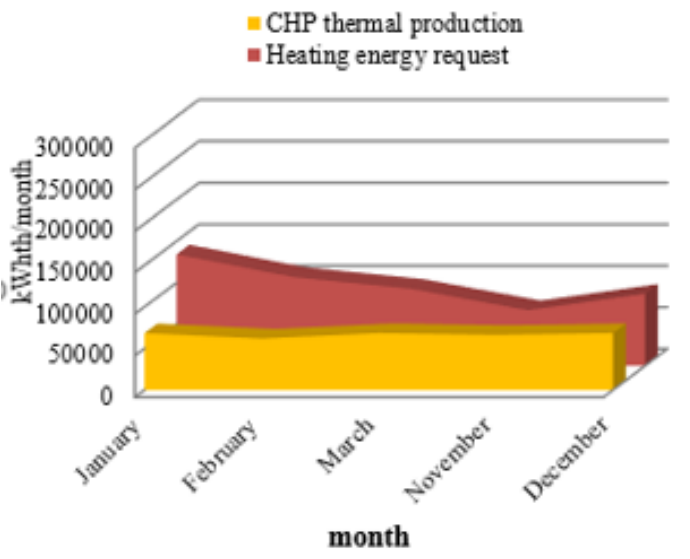

Figure 8. Heating energy demand and CHP heating production in the case of combine intervention (CHP and improving on envelope)

The assumptions to improve energy performance are in accordance with the parameters laid down by the Decree Minimum Requirements for 2021 [16].

Thanks to the reduction of energy requirement, the cogeneration system is allowed to cover heating energy demand most of the heating period.

\section{FEASIBILITY ANALYSIS}

From a study carried out, the cost per $\mathrm{kW}$ for the installation of a cogeneration plant is equal to $3500 € / \mathrm{kW}_{\mathrm{e}}$, from which we derive a total cost of the CHP system of $315000 €$.

Table 5 shows the actual cost to satisfy heating request compared with economic and energy saving related to the installation of CHP system.

Table 5. Actual costs and savings with cogeneration system

\begin{tabular}{c|cc|cc}
\multirow{2}{*}{$\begin{array}{c}\text { Actual } \\
\text { heating and } \\
\text { electricity } \\
\text { consumptions }\end{array}$} & \multicolumn{2}{|c|}{ Gas } & \multicolumn{2}{c}{ Electricity } \\
\cline { 2 - 5 } & Consumption & Costs & Consumption & Costs \\
\cline { 2 - 5 } $\mathrm{m}^{3} /$ year & $€ /$ year & $\mathrm{kWh} /$ year & $€ /$ year \\
\hline \multirow{2}{\text{CHP}}{$\begin{array}{c}\text { CHPduction } \\
\text { production }\end{array}$} & $\begin{array}{c}\text { CHP thermal } \\
\text { production }\end{array}$ & Saving & $\begin{array}{c}\text { CHP } \\
\text { electricity } \\
\text { production }\end{array}$ & Saving \\
\cline { 2 - 5 } $\begin{array}{c}\text { and energy } \\
\text { savings }\end{array}$ & $\mathrm{m}^{3} /$ year & $€ /$ year & $\mathrm{kWh} /$ year & $€ /$ year \\
\cline { 2 - 5 } & 31753 & 25263 & 180326 & 60355 \\
\hline
\end{tabular}

For costs analysis, we used data derived by Annual Report [17] of Italian Regulatory Authority for Electricity and Gas.

Gas costs for users with a gas consumption exceeding 5245 $\mathrm{m}^{3} /$ year is equal to $79.56 \mathrm{c} € / \mathrm{m}^{3}$, while electric energy cost for users with electricity consumption exceeding 15000 $\mathrm{kWh}_{\mathrm{el}} /$ year amounted to $33.47 \mathrm{c} € / \mathrm{kWh}_{\mathrm{el}}$ while the maintenance costs are equal to $2 \mathrm{c} € / \mathrm{kWh}_{\mathrm{el}} *$ year.

The cogeneration system presents an energy saving of $333408 \mathrm{kWh}_{\mathrm{th}} /$ year and $180326 \mathrm{kWh}_{\mathrm{el}}$ and an economic saving of $85618 € /$ year.

Italian Ministry of Economic Development promotes guidelines for defining Cogeneration High Yield (CAR) [18], with which the cogeneration system can access White Certificates.

These guidelines set out the requirements for establishing a cogeneration plant as a CAR (High Efficiency Cogeneration):

- Global performance;

- $\quad$ Ratio between energy/heat $C_{\text {eff }}$;

- $\quad$ PES (Primary Energy Saving);

- $\quad$ Resulting incentive under D.M. 5 September 2011.

In the case of cogeneration with internal combustion engine, the global performance is given by (see Eq. 3):

$\bar{\eta}_{\text {global }}=\frac{E_{c h p}+H_{c h p}}{F_{c h p}}$

For small-cogeneration, the actual ratio between electric production and useful thermal energy $C_{\text {eff }}$ is assumed equal to 0.75 as established by [14]. In our case, the global performance obtained is shown in table 6 .

Table 6 . Global performance of small-cogeneration system

\begin{tabular}{cc|ccc}
\hline \multirow{2}{*}{ Month } & $\mathbf{E}_{\text {chp }}$ & $\mathbf{H}_{\text {chp }}$ & $\mathbf{F}_{\text {chp }}$ & $\begin{array}{c}\text { glob } \\
\text { al }\end{array}$ \\
\cline { 2 - 5 } & $\mathrm{kWh} / \mathrm{month}$ & $\mathrm{kWh}_{\mathrm{th}} / \mathrm{month}$ & $\mathrm{kWh}_{\mathrm{el}} / \mathrm{month}$ & {$[\%]$} \\
\hline January & 33946 & 68448 & 122182 & $84 \%$ \\
\hline February & 34155 & 61824 & 115234 & $83 \%$ \\
\hline March & 37815 & 68448 & 127581 & $83 \%$ \\
\hline November & 36595 & 66240 & 123465 & $82 \%$ \\
\hline December & 37815 & 68448 & 127581 & $83 \%$ \\
\hline Year & $\mathbf{1 8 0 3 2 6}$ & $\mathbf{3 3 3 4 0 8}$ & $\mathbf{6 1 6 0 4 3}$ & $\mathbf{8 3 \%}$ \\
\hline
\end{tabular}

The PES (Primary Energy Savings), defined by [18], is expressed by Equation 4:

$P E S=\left(1-\frac{1}{\frac{C H P H \eta}{\operatorname{Re} f H \eta}+\frac{C H P E \eta}{\operatorname{Re} f E \eta}}\right) \times 100$

The conditions established by Italian law are shown in table 7 and they depend on cogeneration system size.

Table 7. Threshold PES value

\begin{tabular}{l|l}
\hline \multicolumn{2}{c}{ Cogeneration system size } \\
\hline$>1 \mathrm{MW}_{\mathrm{el}}$ & $>10 \%$ \\
\hline $50 \mathrm{~kW}_{\mathrm{el}}<$ small cogeneration units $\left.\leq 1 \mathrm{MW}_{\mathrm{el}}\right)$ & $>0 \%$ \\
\hline micro $\mathrm{CHP}$ unit $\leq 50 \mathrm{~kW}_{\mathrm{el}}$ & $>0 \%$
\end{tabular}

For cogeneration unit designed, the PES value (Table 8) is equal to $17.88 \%$ and this guarantee a high energy savings.

Table 8. Calculation of PES (Primary Energy Savings)

\begin{tabular}{rrrrr}
\hline \multicolumn{5}{c}{ PES } \\
\hline CHP H & Ref H & CHP E & Ref E & PES (\%) \\
\hline 0.54 & 0.82 & 0.29 & 0.53 & $\mathbf{1 7 . 8 8 ~ \%}$
\end{tabular}

The cogeneration system designed satisfies the CAR requirements as stated by [18] and for this reason it can be access to White Certificates incentives. 
The number of White Certificates Incentives is related to the primary energy saving in the year and it is calculated with Equation 5:

$$
R I S P=\frac{E_{c h p}}{\eta_{E} R I F}+\frac{H_{c h p}}{\eta_{T} R I F}-F_{c h p}
$$

The amount of savings achieved by the cogeneration unit is converted into White Certificates (C.B. as indicated by [19]) with the formula (see Eq. 6):

$$
\text { C.B. }=(R I S P \cdot 0.086) \cdot K
$$

Table 9 shows the RISP value and C.B. value for the case study.

Table 9. RISP and C.B. value for the case study

\begin{tabular}{cccc}
\hline RISP & RISP*0.086 & K & C.B. \\
\hline MWh & tep & - & number \\
\hline 183 & 16 & 1.4 & 22
\end{tabular}

Given that a White Certificate is worth $100 € /$ tep, the annual savings for a period of 10 year (maximum period stated by art. 4 paragraph 2 [19] for this type of cogeneration unit) is equal to $€ 2199$.

In the case of a combine intervention (envelope and installation of the cogeneration system described), the annual gas consumptions and costs reduced but, at the same time, investment costs increased.

The intervention costs on envelope amount at $987883 €$.

These typologies of intervention can benefit of Thermal Bill 2.0 [20] incentives, promote by Italian Legislation, which establishes an incentive of $40 \%$ for interventions on horizontal opaque envelope and transparent envelope.

In this case the investment costs amounted at $592730 €$. Table 10 shows the actual cost to satisfy heating request compared with saving relating CHP system designed.

Table 10. Gas consumption and CHP heating savings after envelope improving

\begin{tabular}{ccc}
\hline \multicolumn{2}{c}{ Gas consumption } & Costs \\
\hline $\mathrm{kWh} /$ year & $\mathrm{m}^{3} /$ year & $€ /$ year \\
\hline 487208 & 46401 & 36916 \\
\hline \multicolumn{2}{c}{ CHP thermal production } & Saving \\
\hline $\mathrm{kWh} /$ year & $\mathrm{m}^{3} /$ year & $€ /$ year \\
\hline 333408 & 31753 & 25263 \\
\hline
\end{tabular}

In the end we analysed the energy saving respect to economic benefit of a financial income, as a bank deposit. We performed the calculation considering the annual energy saving in euro constant (this is the most precautionary approach) compared to financial income benefit with a percentage increasing between $0 \%$ to $5 \%$.

Figure 9 shows the increase of money investment rate respect to energy saving.

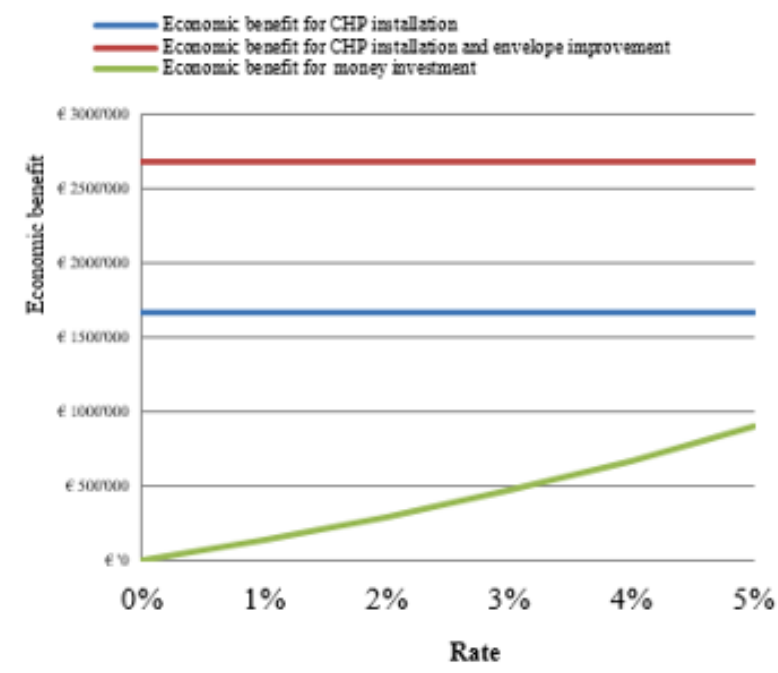

Figure 9. Economic analysis for constant energy costs and different rate of increase in money investment

Even if we considered the percentage of $5 \%$ of financial income, the energy saving allowed an economic benefit of $46 \%$ in the case of only CHP installation and of $66 \%$ in the case of total improvement (envelope + CHP installation).

In the first case, considering the White Certificates incentives, the pay-back time is between 3-4 years with a percentage of energy saving in 20 years (cogeneration system lifetime) of 53\%; while, in the second case, the pay-back time is between 6-7 years with a percentage of energy saving in 20 years (cogeneration system lifetime) of $86 \%$ respect the state of art.

Both pay-back times are independent of the rate of increase in costs and money investment.

\section{CONCLUSIONS}

The analysis conducted on the assumption of a district cogeneration system used by school buildings highlights and confirms that it is a great potential source of energy savings in the building-plant system.

The case study described acts as a driver for the next replicability of the intervention proposed in other similar contexts, since it is configured as a reference criterion, applicable to almost all of the public buildings belonging to the national heritage.

The hypothesis of a unique installation for several buildings stands as a starting point for a proposal for reduction of energy consumption that unifies and reduces the number of thermal plants currently present.

This would allow, thanks to the innovative generation systems, to reduce demand for primary energy and lower maintenance costs borne by the Public Administration.

These actions, in addition to providing solutions to the needs of management optimization of the buildings, also meet the transposition duties of current European and National legislation.

Through the cogeneration system designed we can guarantee an energy savings of $53 \%$ in the case of only 
replacement of plant, and of $86 \%$ in the case of combine intervention on envelope and CHP installation.

Regarding the pay-back time, it is constant even in the case of an increase of price cost rate and it is between 3-4 years in the case of only CHP installation and 6-7 years in the case of combine intervention on envelope and CHP installation.

\section{ACKNOWLEDGMENT}

The work was realized within the FESTA project (Fostering local energy investments in the Province of Matera), financed by European Union's Horizon 2020 research and innovation programme under grant agreement No 649956.

\section{REFERENCES}

[1] Mura P.G., Innamorati R. (2015). Design of a new system of high-power efficiency conditioning cogeneration energy for a building of the University of Cagliari with fossil fuel plants, Energy Procedia, Vol. 78, pp. 1111-1116.

[2] Çakir U., Çomakli K., Yüksel F. (2012). The role of cogeneration systems in sustainability of energy, Energy Conversion and Management, Vol. 63, pp. 196202.

[3] Burer M., Tanaka K., Favrat D., Yamada K. (2003). Multi-criteria optimization of a district cogeneration plant integrating a solid oxide fuel cell-gas turbine combined cycle, heat pumps and chillers, Energy, Vol. 28, pp. 497-518.

[4] Gambarotta A., Vaja I. (2003). La Cogenerazione: produzione combinata di elettricità e calore" in the "La Cogenerazione", Agency for Energy Savings, Ch. 1, Sec. 1, p. 3.

[5] Cammarata G., Cammarata M., D’Amico G., Russo F. (2013). Integrazione degli impianti meccanici-La Cogenerazione, in Edifici ad energia quasi zero, Grafill, Ch. 9, Sec. 9-10, pp. 323-333.

[6] Cannistraro A., Cannistraro G., Cannistraro M., Galvagno A., Trovato G. (2016). Evaluations technical and economic the integrations of co-trigeneration systems in the dairy industry, IJHT, Vol. 34, Special Issue 2, pp. 332-336. DOI: 10.18280/ijht.34S220

[7] Cannistraro G., Cannistraro M., Cannistraro A., Galvagno A., Trovato G. (2015). Evaluation of the convenience of a citizen service district heating for residential use, a new scenario introduced by high efficiency energy system, International Journal of Heat \& Technology, Vol. 33, No. 4, pp. 167-172. DOI: 10.18280/ijht.330421

[8] Italian Law (No. 373/76). (1976). Official Gazette, No. 148.

[9] Italian Law (No. 10/91) (1991). Official Gazette, No. 13, Ordinary Suppl, No. 6.

[10] Thermal insulation -- Building elements - In situ measurement of thermal resistance and thermal transmittance, ISO 9869-1, (2014).

[11] Building components and building elements -- Thermal resistance and thermal transmittance - Calculation method, UNI EN ISO 6946, (2008).
[12] Thermal performance of windows, doors and shutters - Calculation of thermal transmittance, UNI EN ISO 10077 1-2, (2012).

[13] U.S. Department of Energy's (DOE) Building Technologies Office (BTO) Energy Plus, from https://energyplus.net/downloads

[14] Legislative Decree. (2007). Implementation of Directive 2004/8 / EC on the promotion of cogeneration based on a useful heat demand in the internal energy market and amending Directive 92/42 / EEC, Official Gazette, No. 54.

[15] Energy performance of buildings-Part 4: Renewable energy and other generation systems for space heating and domestic hot water production, UNI/TS 11300-4, 2016

[16] Inter-ministerial Italian Decrees. (2015). Decree for minimum requirements: application of the calculation methodology of the energy performance and definition of requirements and minimum requirements for buildings, GU No. 162, Ordinary Suppl, No. 39.

[17] Bortoni G., Biancardi A., Carbone G., Colicchio R., Termini V. (2016). Annual report on the state of services and activity carried out, Italian Regulatory Authority for Electricity and Gas, Italy.

[18] Guidelines for the application of the Decree of Ministry of Economic Development on September 5, 2011Cogeneration High Yield (CAR). (2011). from http://www.gse.it/it/qualifiche\%20e\%20certificati/cert ificati\%20bianchi\%20e\%20car/Riconoscimento\%20C AR/Pages/default.aspx.

[19] Ministerial Decree of 5 September 2011-Support system for high-efficiency cogeneration, 201. (2011). from

http://www.sviluppoeconomico.gov.it/index.php/it/com ponent/content/article?id=2020499.

[20] Thermal Bill, 2.0 Ministerial Decree. (2016). from: http://www.gse.it/it/Conto\%20Termico/Conto\%20Ter mico\%202.0/Pagine/default.aspx.

\section{NOMENCLATURE}

$\eta \quad$ Global energy performance, dimensionless

$Q_{e l} \quad$ Fuel energy converted into electricity, $\mathrm{kWh}_{\mathrm{el}}$

$Q_{t h} \quad$ Fuel energy converted into heat, $\mathrm{kWh}_{\mathrm{th}}$

$Q_{c h} \quad$ Energy given by fuel, $\mathrm{kWh}_{\text {th }}$

$\alpha \quad$ Congruity index, dimensionless

$Q_{C G, s} \quad$ Useful heat storage capacity, $\mathrm{kWh}_{\text {th }}$

$Q_{C G, s, d e s i g n} \quad$ Designed heat storage capacity, $\mathrm{kWh}_{\text {th }}$

$\bar{\eta}_{\text {global }} \quad$ Minimum value of the global performance necessary in order to consider a unit of high efficiency cogeneration in its entirety. It can be $75 \%$ or $80 \%$ depending on the type of unit. In cogeneration with internal combustion engine is equal to 75 , dimensionless

$H_{c h p} \quad$ Thermal energy provided by a cogeneration unit to an area of user or to an industrial process in the reporting period, $\mathrm{kWh}_{\text {th }}$

$E_{c h p} \quad$ Electric/gross mechanical energy that is produced in function of the heat CHP useful in the reporting period, $\mathrm{kWh}_{\mathrm{el}}$

$F_{c h p} \quad$ Fuel energy based on the lower calorific value (P.C.I.) required in a cogeneration process to simultaneously produce electrical / mechanical 
energy and useful heat $\mathrm{CHP}$ in the reporting period, kWh

$C_{\text {eff }} \quad$ Ratio between the electrical/mechanical energy gross CHP ( $\left.E_{\text {chp }}\right)$ and useful thermal energy CHP $\left(\mathrm{H}_{\mathrm{chp}}\right)$ in the reporting period, dimensionless

PES Primary energy savings, \%

CHP $H$ Thermal efficiency of production by means of cogeneration defined as the ratio between the useful heat $\left(\mathrm{H}_{\mathrm{chp}}\right)$ divided by the fuel input $\left(\mathrm{F}_{\mathrm{chp}}\right)$ used to produce the sum of the heat from cogeneration and useful electrical energy, dimensionless

Ref $H \quad$ Yield value for the separate production of heat in accordance with the parameters given in Annex V of D.M. 5 September 2011, dimensionless

CHP E Electrical production yield cogeneration defined as the ratio between the electricity produced in the cogeneration $\left(\mathrm{E}_{\mathrm{chp}}\right)$ and the fuel input $\left(\mathrm{F}_{\mathrm{chp}}\right)$ used to produce the sum of the heat from cogeneration and useful electrical energy, dimensionless

Ref $E \quad$ Reference value for the separate production of electricity according to the parameters listed in Annex IV of D.M. 5 September 2011, dimensionless

$\lambda \quad$ Thermal conductivity, $\mathrm{W} / \mathrm{mK}$

RISP Primary energy savings produced by the cogeneration unit, MWh,

$\eta_{E} R I F \quad$ Conventional average efficiency of the Italian electricity production park, assumed to be equal to 0.46 , dimensionless

$\eta_{T} R I F \quad$ Conventional average efficiency of the heat production park Italian, assumed equal to 0.82 in the case of direct use of the exhaust gas; 0.90 in the case of production of steam / hot water; dimensionless

C.B. Number of White Certificates, TEP

K Harmonization coefficient set equal to 1.4 for cogeneration unit <1 MWe, dimensionless 